\title{
Are cloud forest tree structure and environment related in the Venezuelan Andes?
}

\author{
TERESA SCHWARZKOPF, ${ }^{1 \star}$ SUSAN J. RIHA, ${ }^{2}$ TIMOTHY J. FAHEY ${ }^{3}$ AND \\ STEPHEN DEGLORIA ${ }^{4}$ \\ ${ }^{1}$ Instituto de Ciencias Ambientales y Ecológicas (ICAE), Facultad de Ciencias, Núcleo La Hechicera, \\ Universidad de Los Andes, Mérida 5101,Venezuela (Email: teresas@ula.ve); and Departments of \\ ${ }^{2}$ Earth and Atmospheric Sciences and ${ }^{3}$ Natural Resources and ${ }^{4}$ Crop and Soil Sciences, Cornell \\ University, Ithaca, New York, USA
}

\begin{abstract}
Cloud forest vegetation structure and composition were studied in the Venezuelan Andes at three sites in Mérida State. Although the sites are within 10 to $30 \mathrm{~km}$ of each other, climatic, geologic and topographic differences are remarkable. The main purpose of the study was to determine the relationship of specific environmental variables to forest vegetation characteristics, including basal area, tree height, density and diversity, and leaf area index (LAI). At 51 plots, all trees' diameter at breast height $>10 \mathrm{~cm}$ were recorded and identified. Although the environment at the three sites is distinctive, the tree species composition of the most abundant species was very similar. None of the measured environment variables were significantly correlated with the measured vegetation structure variables, except LAI, which was correlated with slope orientation; LAI showed higher values at southfacing plots. Tree height was relatively uniform, while basal area was highly variable and reached very high values. Stem densities were in the range reported elsewhere in cloud forests. Multivariate analysis using structure or composition data shows segregation of the plots by site. Principal component analyses by site indicate a minor impact of environmental factors on forest variables. At each site, a particular group of species are correlated with the ordination axes. We conclude that species pools and forest dynamics add to the complexity of the structure of the studied cloud forests.
\end{abstract}

Key words: basal area, elevation, leaf area index, slope, topography.

\section{INTRODUCTION}

The presence of a belt of cloud forest vegetation on mountains in the tropics has been attributed to a significant local increase in water availability because of orographic precipitation and an increase in cloudiness (Grubb 1977; Bruijnzeel \& Proctor 1995; Ataroff 2001), resulting in part from decreasing temperature along the elevation gradient. Less attention has been given to the variability in vegetation structure within elevation ranges of cloud forest belts. Although the presence of cloud forests is correlated with fog frequency rather than temperature (Grubb 1977; Cavalier \& Goldstein 1989), within the cloud forest belt, vegetation structure, especially tree height, has been related to various factors associated with elevation, like temperature, precipitation and relative humidity (Bruijnzeel \& Veneklaas 1998; Ataroff 2001).

However, some observations indicate a significant variability in forest structure not explained by elevation only. Several studies on the impact of topography,

${ }^{\star}$ Corresponding author.

Accepted for publication April 2010. fire, geology and succession on the variability of cloud forests (Haggar 1988; Guariguata 1990; Myster 1993; Takyu et al. 2002, 2003; Aiba et al. 2005; Martin et al. 2007) suggest complex forest-environment interactions and regional uniqueness. Moreover, the relationships between cloud forest vegetation and environmental factors are still not well understood.

In the Venezuelan Andes, high species diversity and the large number of endemic species (Kelly et al. 1994) have been attributed to topographic, geologic and climatic complexity (Soriano et al. 1999). Natural disturbances in Andean cloud forests are usually small in contrast to cloud forests in the Caribbean and Central America where hurricanes and fire are common. Neither the impact of disturbances nor abiotic factors on cloud forest tree structure have been addressed in Andean cloud forests. As topography is fairly complex in the Andean mountains, a high degree of variability in cloud forest structure can be expected. Although Nadkarni et al. (1995) suggest that similar environmental conditions do not imply similar forest structure or composition, it is expected that, at a smaller scale, topographic features impact cloud forest vegetation, as those affect temperature; stimulate 
orographic precipitation; reduce radiation load because of slope, aspect, cloudiness and mountain shading; and have a significant impact on soil properties.

The aim of this study was to explore the impact of environmental gradients on cloud forest vegetation. We focused on the structure of the forest, although floristic composition and richness were analysed with respect to their impact on forest structure. Three sites in the Venezuelan Andes were studied to address the following questions: (i) Is cloud forest structure different among sites? (ii) Do environmental gradients correlate with forest structure across sites? (iii) How is forest composition related to environmental variables and to forest structure? and (iv) Is canopy structure correlated with topography?

\section{METHODS}

\section{Study area}

This study was conducted in cloud forest areas near the city of Merida in the Venezuelan Andes (Fig. 1). Three study sites were selected in protected areas: (i) La Mucuy $\left(8^{\circ} 37.65^{\prime} \mathrm{N}\right.$, $71^{\circ} 02.28^{\prime} \mathrm{W}$ ) in the Parque Nacional Sierra Nevada; (ii) Monte Zerpa $\left(8^{\circ} 38.10^{\prime} \mathrm{N}, 71^{\circ} 09.73^{\prime} \mathrm{W}\right)$ in the Parque
Nacional Sierra de La Culata; and (iii) La Carbonera $\left(8^{\circ} 39\right.$. $\left.54^{\prime} \mathrm{N}, 71^{\circ} 24.20^{\prime} \mathrm{W}\right)$, a protected area, near San Eusebio, owned by the Universidad de Los Andes. The three forests may have been subject to some logging before the declaration of protected areas after 1950. Unfortunately, no report on the extent and intensity of the impact was available; however, no stumps or evidence of deforestation is visible. The first two sites belong to the Chama river watershed and the third one to the Capaz river watershed. The three sites have a bimodal precipitation pattern, with one peak in April-May and another in October. The mean annual precipitation in the three sites is markedly different at similar elevations: $2929 \mathrm{~mm}$ at La Mucuy (2217 m), $2008 \mathrm{~mm}$ near Monte Zerpa $(1920 \mathrm{~m})$ and $1544 \mathrm{~mm}$ at La Carbonera $(2240 \mathrm{~m})$. Precipitation is fairly variable between years (Acevedo et al. 2003) and between locations at La Mucuy (Ataroff, pers. obs). Unfortunately, no climate data were available along the elevation gradient on any of the sites. Mean annual temperatures are similar among the three sites $\left(11-14^{\circ} \mathrm{C}\right.$ ) (Rollet 1984; Ataroff 2002) with small annual variation (Ataroff 2002). Recent continuous temperature recordings at the Sierra Nevada indicate that mean temperature decreases and daily temperature oscillations increase with elevation at cloud forest locations (http://www.ing.ula.ve/\%7Ecme/red.html); however, no subfreezing temperatures have been registered at cloud forest elevations.

The geology of the study area is complex and diverse. At La Mucuy, the 'Complejo Iglesias' dominates, which is characterized by igneous and metamorphic rocks of pre-

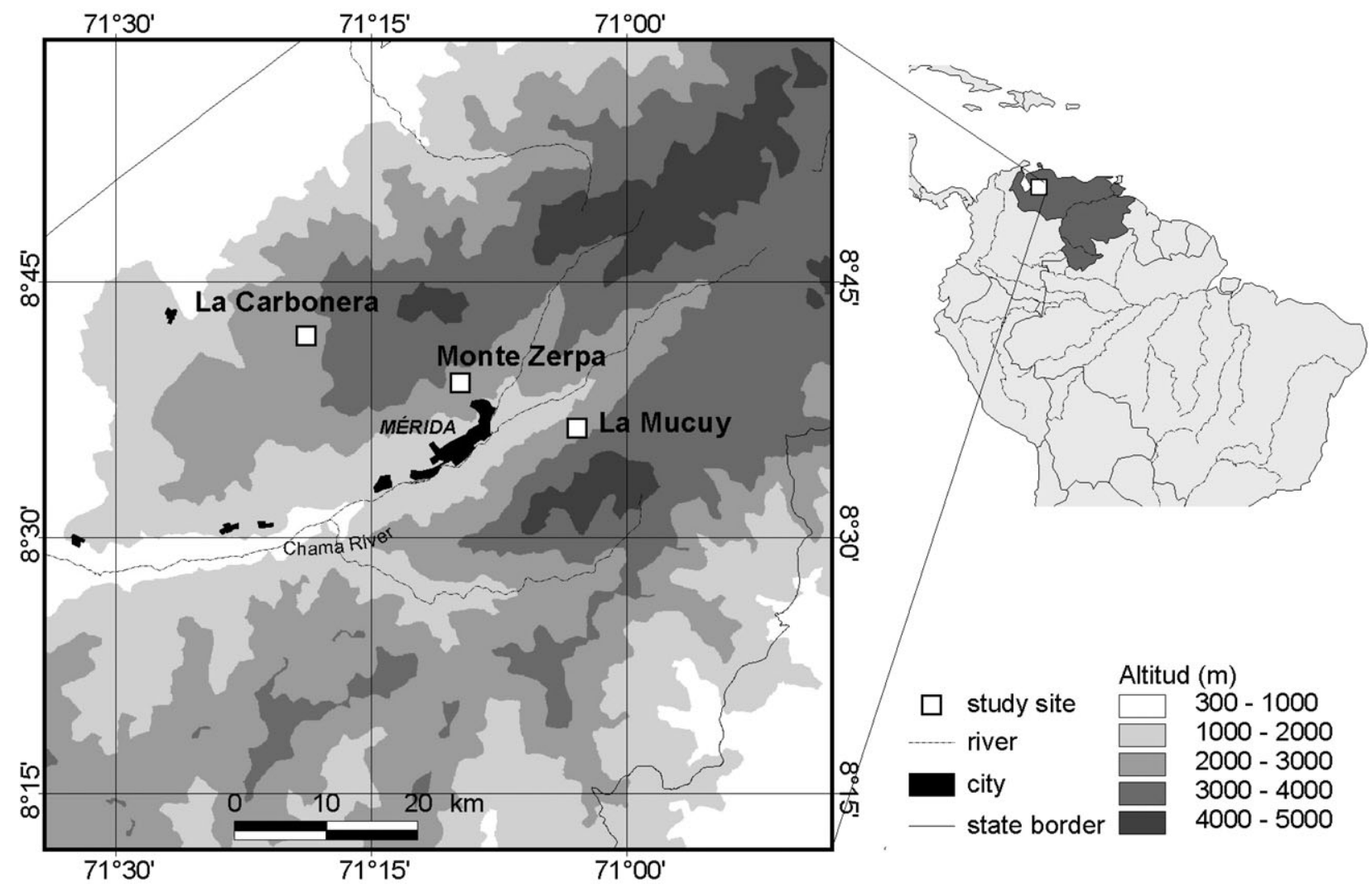

Fig. 1. Map showing localization of the three study sites. 
Cambrian times. At Monte Zerpa, the 'Complejo Iglesias' and the 'Formación Mirador' are the most conspicuous geologic formations. The latter is composed of sandstone and limestone from the Palaeocene-Eocene period. At La Carbonera, the 'Formación Colón' and the 'Formación Mirador' are the predominant geological formations. The former is composed of limestone from the Cretaceous (Dirección de Geología 1976; Ministerio de Energía y Minas 1997).

\section{Sampling and data analysis}

With the aid of ARC-INFO software, digital elevation models were used to create digital maps of topographic features (slope, aspect and elevation) based on a digitized version of the Venezuelan topographic map (Dirección de Cartografía Nacional 1977) with a contour interval of $40 \mathrm{~m}$ and 1:100 000 scale. ARC-INFO was also used to overlay this map with a map of ecological units (Ataroff \& Sarmiento 2002) and to select the areas occupied by cloud forest units. The geological units of the area were digitized from a geologic map (Dirección de Geología 1976). For the cloud forest areas in the 5941 map sheet, the percentage area occupied by each geologic unit, slope steepness, aspect and elevation were estimated. These percentages were then used to stratify plots across the landscape (see below).

Plots were located randomly along hiking/mule paths at each study site, far enough from the path to avoid impacts from path users. The percentage of plots in different environmental categories (slope, aspect, elevation and geological unit) was assessed at several stages during fieldwork, and sampling was intensified in underrepresented physiographic categories. A total of 51 circular plots was established. Six plots at La Carbonera were 0.0962 ha in size, and the remaining 45 plots were 0.0625 ha in size. Sixteen, 15 and 20 plots were sampled at La Mucuy, Monte Zerpa and La Carbonera, respectively. At each plot, the following measurements were taken:

1. Latitude and longitude coordinates were recorded at the centre of the plot with a handheld Geographical Positioning System (Garmin12-channel).

2. Leaf area index (LAI) was estimated by gap fraction analysis using hemispherical photography (Rich 1990). This was performed with a digital canopy analyser (CID110). Between three and five pictures were taken per plot; one image was captured at the centre of the plot, and two to four other images were taken halfway between the centre and the border of the plot in main cardinal directions. Because of equipment failure, only 46 of the 51 plots were sampled, 14 each at the Monte Zerpa and La Mucuy sites, and 18 at the La Carbonera site.

3. The slope and maximum tree height of each plot were measured with a digital hypsometer (Haglof, Vertex III). Slope orientation was determined with the aid of a handheld compass.

4. Soil depth and depth of the organic horizon were determined in the field, and soil samples were taken at $30 \mathrm{~cm}$ depth intervals with the aid of a soil corer. Soil depth was determined as the depth at which the soil corer reached bedrock. When the bedrock was deeper than the length of the soil corer $(1.5 \mathrm{~m})$, the soil depth was recorded as
$1.5 \mathrm{~m}$. The depth of the organic layer was defined as the Ao and A horizon of the soil profile, which was qualitatively based on change in colour from dark brown to yellowish tones and was easy to identify. At least three replicates were taken at randomly selected points within each plot. The samples were taken to the lab where texture and $\mathrm{pH}$ were measured. Texture was estimated by the feel method (Tien 1979), and soil $\mathrm{pH}$ was determined by means of an automatic 702 SM Titrino-Metrohm.

5. Each tree with a diameter at breast height $(\mathrm{DBH})$ greater or equal to $10 \mathrm{~cm}$ within the plot's perimeter was tagged, and its DBH was recorded, identified with the aid of field experts and specimens, and compared with the collection of the Herbario MER.

Data were standardized and prepared for multivariate analysis. Because of the length of the gradients, 'horseshoe effect' was avoided using detrended correspondence analysis (DCA). When shorter gradients were analysed and no horseshoe effect was apparent, principal component analysis (PCA) was performed. PC-ORD, a multivariate analysis software (McCune \& Mefford 1999), was used to perform these analyses. The relationships among vegetation and environmental variables were evaluated by correlation analyses. The vegetation structure variables used were tree height, live and dead tree density, live basal area, maximum individual $\mathrm{DBH}$, number of live species and LAI. The environmental variables used in the analyses were: elevation, slope steepness, slope aspect, soil depth, soil $\mathrm{pH}$, soil texture, geologic substrate and depth of organic soil layer. One-way analysis of variance (ANOVA) was carried out to test the significance of the relationships of single environmental categorical variables and vegetation variables. Additional two sample $t$-tests assuming unequal variances were carried out to test the significance of differences observed among pairs of means.

\section{RESULTS}

Three sites were selected to encompass the environmental variability of cloud forest areas in the region. The ranges of the environmental variables measured on plots at the three sites were large, and most had a significant overlap among sites (Table 1); however, the three sites also exhibited some distinctive features. For example, Monte Zerpa had coarser textured soils with thick organic layers, La Mucuy had steeper slopes and higher soil $\mathrm{pH}$, and La Carbonera had gentler slopes with deeper mineral soils. Average annual precipitation and geology were also different among sites.

A total of 2462 stems $(\mathrm{DBH}>10 \mathrm{~cm}$ ) were measured and tagged. These stems belonged to 71 species and 37 families. Tree species composition at the three sites was similar: $67 \%$ of the species with more than 40 stems in the 51 plots were present at the three sites, $22 \%$ at two sites and $11 \%$ at only one site. Results summarized in Table 2 indicate that the three forests were comparable in composition of the dominant species, although their relative importance differed in most species. 
Table 1. Topographic and edaphic variables measured among plots and summarized by site, and mean annual precipitation by site

\begin{tabular}{lccc}
\hline & Monte Zerpa & La Mucuy & La Carbonera \\
\hline Elevation [range] (m) & $2219[2040-2800]$ & $2588[2290-3050]$ & $2321[2220-2440]$ \\
Slope steepness [range] (deg) & $24.2[7-47]$ & $38.3[28-55]$ & $14.1[2-27]$ \\
Average soil depth [range] $(\mathrm{cm})$ & $79.9[38-125]$ & $81.6[25-133]$ & $135.8[108-150]$ \\
Avg. depth of organic layer [range] $(\mathrm{cm})$ & $70.5[38-100]$ & $34.0[5-83]$ & $29.2[25-58]$ \\
Average pH [range] & $5.0[4.5-5.7]$ & $5.2[4.4-6.2]$ & $4.8[4.2-5.1]$ \\
Most common plot orientation & South $(50 \%)$ & West $(64 \%)$ & North $(50 \%)$ \\
Most frequent soil texture & Sand & Loam & Clay \\
Mean annual precipitation (mm) & 2008 & 2929 & 1544 \\
\hline
\end{tabular}

The range of values found in plots at each site in brackets.

Table 2. Average live stem density and basal area (in brackets) $\left(\mathrm{cm}^{2} \mathrm{~m}^{-2}\right)$ for the 10 most abundant species in the study

\begin{tabular}{lccc}
\hline Species & Monte Zerpa & La Mucuy & La Carbonera \\
\hline Inga oerstediana & $4.42[47]$ & $3.00[20]$ & $2.71[14]$ \\
Alcornea gradiflora & $4.00[40]$ & $3.83[16]$ & $1.51[3]$ \\
Miconia meridensis & $3.54[12]$ & $3.92[17]$ & $5.31[14]$ \\
Clusia multiflora & $3.50[23]$ & $10.57[11]$ & $3.54[4]$ \\
Hedyosmum racemosum & $3.00[7]$ & $3.43[15]$ & $2.45[7]$ \\
Billia columbiana & $3.00[17]$ & $5.83[12]$ & $9.70[16]$ \\
Myrcia fallax & $2.30[3]$ & $5.33[25]$ & $2.27[5]$ \\
Beishmiedia sulcata & $1.67[11]$ & $1.00[1]$ & $8.06[15]$ \\
Axinaea grandiflora & $1.00[1]$ & $5.30[19]$ & $3.48[8]$ \\
Ruagea pubescens & & & \\
\hline
\end{tabular}

Table 3. Average vegetation structure variables at the three sites (51 plots)

\begin{tabular}{lcrr}
\hline & Monte Zerpa & La Mucuy & La Carbonera \\
\hline Total live basal area $\left(\mathrm{cm}^{2} \mathrm{~m}^{-2}\right)$ & $48.7(43.9)^{\mathrm{a}}$ & $165.5(157.6)^{\mathrm{b}}$ & $38.3(12.6)^{\mathrm{a}}$ \\
Stem density $\left.(\mathrm{stems} \mathrm{ha})^{-1}\right)$ & $365.9(123.5)^{\mathrm{a}}$ & $723.0(315.3)^{\mathrm{b}}$ & $850.1(292.2)^{\mathrm{b}}$ \\
Canopy height $(\mathrm{m})$ & $23.7(4.8)^{\mathrm{ab}}$ & $20.9(6.2)^{\mathrm{a}}$ & $26.7(6.7)^{\mathrm{b}}$ \\
Live basal area/canopy height & $2.1(1.8)^{\mathrm{a}}$ & $8.4(7.96)^{\mathrm{b}}$ & $1.4(0.4)^{\mathrm{a}}$ \\
Tree species density (spp. plot $\left.{ }^{-1}\right)$ & $9.13(2.85)^{\mathrm{a}}$ & $16.31(6.30)^{\mathrm{b}}$ & $14.45(4.98)^{\mathrm{b}}$ \\
Leaf area index & $2.4(0.4)^{\mathrm{a}}$ & $2.1(0.5)^{\mathrm{b}}$ & $2.3(0.3)^{\mathrm{ab}}$ \\
\hline
\end{tabular}

Numbers in parenthesis are standard deviations. Superscripts refer to two-sample, two-tailed, unequal variance $t$-tests; different letters mean that they are significantly different $(P<0.05)$.

Vegetation structure variables measured at each plot were averaged by site and are presented in Table 3. All variables were different among sites (ANOva $P<0.05$ ). Interestingly, each site can be characterized by a distinctive suite of structural features. La Mucuy had the largest live basal area and live basal area/canopy height ratio. Monte Zerpa had smaller stem and species densities, and La Carbonera exhibited larger canopy heights. The live basal area/canopy height ratio was used as a measure of tree stunting. La Mucuy showed the highest average ratio, which is at least four times larger than at the other sites. However, these differences are due only to basal area increase, as no tree height decrease was observed, except in one plot above
$3000 \mathrm{~m}$ (plot M16 at $3050 \mathrm{~m}$ ). Moreover, at La Mucuy, seven plots with the larger basal areas had, on average, eight times larger basal areas than the rest of the plots.

In spite of the differences in structure among sites, no correlations were found between structural variables and environmental variables measured at the plot scale. As categorical data like soil texture, slope aspect and geology are not suitable for correlation analyses, the relationship of these variables and the vegetation structure were analysed by grouping the plots into categories, with one-way ANOVA and two sample $t$-tests. Only slope aspect categories were significantly different relative to some of the vegetation structure 


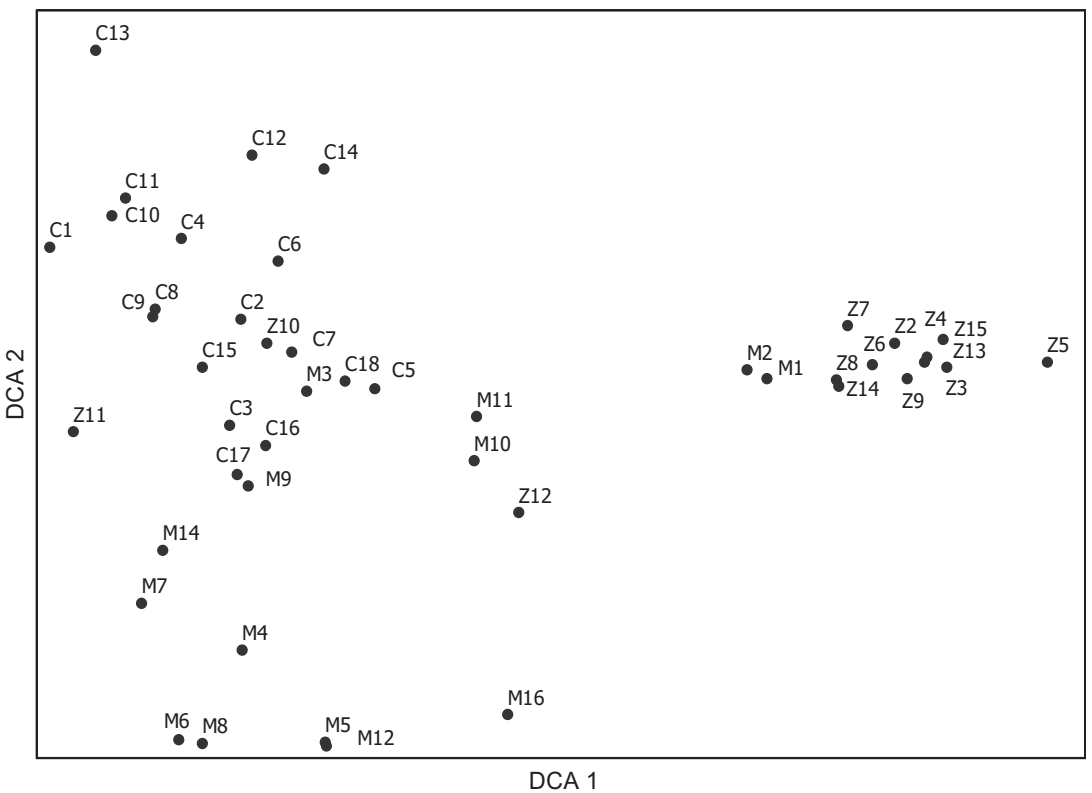

Fig. 2. First two axes of detrended correspondence analysis (DCA) on 20 most important species based on \% basal area per plot. Z-labelled plots correspond to Monte Zerpa site, M to La Mucuy and C to La Carbonera.

variables. In fact, LAI was significantly higher on south-facing plots (2.7) than on north-facing plots (1.7), a result that was consistent across sites. Stem density is significantly lower on east-facing plots than on north- and west-facing slopes, while live basal area is significantly higher on west-facing plots compared with north- and east-facing slopes. The high live basal area on west-facing slopes was related to the fact that $64 \%$ of the plots at La Mucuy, the site with the largest basal areas, were west oriented. Also, the low stem density on east-facing slopes reflected their high occurrence $(60 \%)$ at Monte Zerpa, the site with lower stem densities.

We analysed the data for the 20 most important species in terms of basal area, using DCA. Resulting scores were displayed among the first two ordination axes (Fig. 2). DCA 1 explained $25 \%$ of the variability, and DCA 2 explained $16 \%$ of the variability. DCA 1 separated a small group of predominantly Monte Zerpa plots on the right side of the diagram. The second axis (DCA 2) separated La Mucuy plots at the bottom and $\mathrm{La}$ Carbonera plots at the end of the axis. However, some overlap among contiguous groups could be observed. Both axes were correlated with single structure and environmental variables (Table 4, first two columns). DCA 1 correlations were dominated by diversity and live and dead stem density, and among the environmental variables, the correlations were dominated by elevation, depth of organic layer and soil depth. Percent basal area of the 20 species included in the analysis showed that only Billia columbiana and Aegiphila terniflora were not correlated with any of the ordination axes, twelve species were only correlated with one axis (six species each) and five species were correlated with both axes.

A multivariate analysis (DCA) was performed with the structure variables measured at each plot, and the resulting axes were checked for correlations with structure, environment and tree species variables. The resulting ordination is shown in Figure 3. The first axis was clearly dominant with $55 \%$ of the variability, while the second axis only explained $4 \%$ of the variability. In fact, the first axis (DCA 1) separated the plots in three groups, although some overlap was evident. The group at the left was dominated by La Carbonera plots, the middle group dominated by Monte Zerpa plots and the right one included only La Mucuy plots. The group of La Carbonera plots at the left end of the axis was probably related to the larger amount of standing dead trees and higher live stem density, while the group of La Mucuy plots at the right end of the ordination corresponded to the plots with the highest basal areas. The correlations of the structure variables, the environmental variables and the percent basal area of the 20 most important species with the two main axes of the structure DCA shown in Figure 3 are presented in Table 4 (third and fourth column). All included structure variables, except LAI, were significantly correlated with both ordination axes. Average and maximum DBH were correlated only with DCA 1, while tree height and species richness were only correlated with DCA 2; however, the percent variability explained by this axis was very low. All environmental variables except elevation were correlated with DCA 1. Fifty percent of the species were correlated with DCA 1 and only one species (Inga oerstediana) with DCA 2. 
Table 4. Significant correlations of first two ordination axes of DCA (structure and species) with single variables and PCA for structural variables by site

\begin{tabular}{|c|c|c|c|c|c|c|c|c|c|c|}
\hline & \multicolumn{2}{|c|}{ All plots species } & \multicolumn{2}{|c|}{ All plots structure } & \multicolumn{2}{|c|}{ Monte Zerpa } & \multicolumn{2}{|c|}{ La Mucuy } & \multicolumn{2}{|c|}{ La Carbonera } \\
\hline & $\begin{array}{c}\text { DCA } 1 \\
55 \%\end{array}$ & $\begin{array}{c}\text { DCA } 2 \\
4 \%\end{array}$ & $\begin{array}{c}\text { DCA } 1 \\
25 \%\end{array}$ & $\begin{array}{c}\text { DCA } 2 \\
16 \%\end{array}$ & $\begin{array}{c}\text { PCA } 1 \\
35 \%\end{array}$ & $\begin{array}{c}\text { PCA } 2 \\
26 \%\end{array}$ & $\begin{array}{c}\text { PCA } 1 \\
36 \%\end{array}$ & $\begin{array}{c}\text { PCA } 2 \\
27 \%\end{array}$ & $\begin{array}{c}\text { PCA } 1 \\
49 \%\end{array}$ & $\begin{array}{c}\text { PCA } 2 \\
18 \%\end{array}$ \\
\hline \multicolumn{11}{|l|}{ Structure variables } \\
\hline Tree height & & & & $\star \star \star$ & & & & & $(-)^{\star \star \star}$ & \\
\hline Live stem count & $(-)^{\star \star \star}$ & & $\star \star \star$ & $(-)^{\star \star \star}$ & $(-)^{\star \star \star}$ & & $\star \star \star$ & & $\star \star \star$ & \\
\hline Dead stem count & $(-)^{\star \star \star}$ & $\star \star \star$ & $\star \star \star$ & $\star$ & & & & $(-)^{\star}$ & & $(-)^{\star \star \star}$ \\
\hline Average DBH & & $(-)^{\star \star \star}$ & $(-)^{\star \star \star}$ & & $\star \star \star$ & $(-)^{\star}$ & $\star \star \star$ & & $(-)^{\star \star \star}$ & \\
\hline Live basal area & & $(-)^{\star \star \star}$ & $(-)^{\star \star \star}$ & $(-)^{\star}$ & & $(-)^{\star \star \star}$ & $\star \star \star$ & & $(-)^{\star \star \star}$ & \\
\hline Maximum DBH & & $(-)^{\star \star \star}$ & $(-)^{\star \star \star}$ & & $\star \star \star$ & & & $(-)^{\star}$ & $(-)^{\star \star \star}$ & \\
\hline Live species count & $(-)^{\star \star \star}$ & & & $(-)^{\star \star \star}$ & $(-)^{\star \star \star}$ & & $\star \star \star$ & & & \\
\hline Diversity $\left(\mathrm{H}^{\prime}\right)$ & $(-)^{\star \star \star}$ & & $\star \star \star$ & $(-)^{\star}$ & & $(-)^{\star}$ & & $(-)^{\star \star \star}$ & & $\star \star \star$ \\
\hline Leaf area index & & & & & & & & $\star$ & $(-)^{\star \star \star}$ & \\
\hline \multicolumn{11}{|l|}{ Environment variables } \\
\hline Elevation & $(-)^{\star \star \star}$ & $(-)^{\star \star \star}$ & & $(-)^{\star}$ & $(-)^{\star \star \star}$ & & & & & \\
\hline Slope angle & & $(-)^{\star \star \star}$ & $(-)^{\star}$ & & $(-)^{\star \star \star}$ & & & & & \\
\hline Soil depth & $(-)^{\star \star \star}$ & $\star \star \star$ & $\star \star \star$ & & & & & $(-)^{\star \star \star}$ & & \\
\hline Depth organic layer & $\star \star \star$ & & $(-)^{\star}$ & & & & & & & \\
\hline Soil $\mathrm{pH}$ & & $(-)^{\star}$ & $(-)^{\star}$ & & & & & & & \\
\hline \multicolumn{11}{|l|}{ Species } \\
\hline Aegiphila terniflora & & & & & & & $\star$ & & & \\
\hline Aiouea dubia & $(-)^{\star}$ & $(-)^{\star}$ & & & & & * & & & \\
\hline Alchornea grandiflora & $\star \star \star$ & & & & 夫 & & & & & * \\
\hline Aniba sp. & $\star \star \star$ & & $(-)^{\star}$ & & & & & & & \\
\hline Axinaea grandifolia & $(-)^{\star \star \star}$ & $\star \star \star$ & $\star \star \star$ & & & & & & $\star \star \star$ & $(-)^{\star}$ \\
\hline Beischmiedia sulcata & & $(-)^{\star}$ & & & & & & $(-)^{\star}$ & & \\
\hline Billia columbiana & & & & & $(-)^{\star}$ & & & & & \\
\hline Clusia multiflora & $(-)^{\star \star \star}$ & $\star$ & $\star$ & & $(-)^{\star}$ & & & & & \\
\hline Eischweilera monosperma ${ }^{M Z} L M$ & & $\star \star \star$ & $\star \star \star$ & & & & & & & \\
\hline Hedyosmum racemosum & $(-)^{\star \star \star}$ & $(-)^{\star \star \star}$ & & & & & * & & $\star \star \star$ & \\
\hline Hyeronima cf. oblonga & $(-)^{\star}$ & $\star \star \star$ & * & & & & & $(-)^{\star \star \star}$ & & \\
\hline Inga oerstediana ${ }^{L C}$ & $\star \star \star$ & & $(-)^{\star}$ & $\star$ & & & & & & \\
\hline Miconia meridensis & $\star \star \star$ & & & & & & & & & \\
\hline Myrcia fallax & $(-)^{\star \star \star}$ & & * & & & & & & & \\
\hline Myrcianthes myrsinoides $^{M Z}$ & & $\star$ & $\star$ & & & & & & & \\
\hline Podocarpus oleifolius & $(-)^{\star \star \star}$ & & $\star \star \star$ & & & & & & & $\star$ \\
\hline Prunus spherocarpa & & $(-)^{\star \star \star}$ & & & & & & & & $\star$ \\
\hline Ruagea pubescens ${ }^{M Z}$ & & $(-)^{\star \star \star}$ & & & & & & & & \\
\hline Zahthoxylum tachirense $e^{M Z}$ & & $\star$ & $\star \star \star$ & & & & & & $\star \star \star$ & \\
\hline
\end{tabular}

${ }^{\star} \star \star$ Significant at $P<0.01$ and at ${ }^{\star} P<0.05$. (-) are negative correlations. $\%$ refers to variance explained by axis. Superscripts MZ, LM and LC are sites (Monte Zerpa, La Mucuy and La Carbonera, respectively) where the species was absent. DCA, detrended correspondence analysis; PCA, principal component analysis.

As the three sites showed some degree of segregation in the species and the structure DCAs, separate analysis by site may allow a better understanding of relationships among environment, forest composition and structure, and may reduce noise. Single PCAs were performed at each site based on the same structure variables used in the structure DCA. Correlation analyses were performed with the first two axes of the three PCAs as previously performed with the DCAs. These results are shown in the last six columns in Table 4. Environmental variables showed few significant correlations with PCA axes compared with the DCA. Only soil depth was significantly correlated at La Mucuy, and at Monte Zerpa, only elevation and slope showed a significant correlation. Interestingly, tree height was only significant at La Carbonera. However, live stem count, DBH, basal area and diversity were significant at the three sites. LAI, which was not correlated with any of the analysed DCA axes, correlated significantly with PCA axes at La Mucuy and La Carbonera. The percent basal area of species showed distinctive correlations with PCA axes among sites. None of the species were correlated with any of the axes at all three sites; only two species (Alchornea grandiflora and Hedyosmum racemosum) were correlated at two sites, while 10 species correlated only at one site. Moreover, 5 of the 10 species with significant correlations in the structure DCA were not correlated 


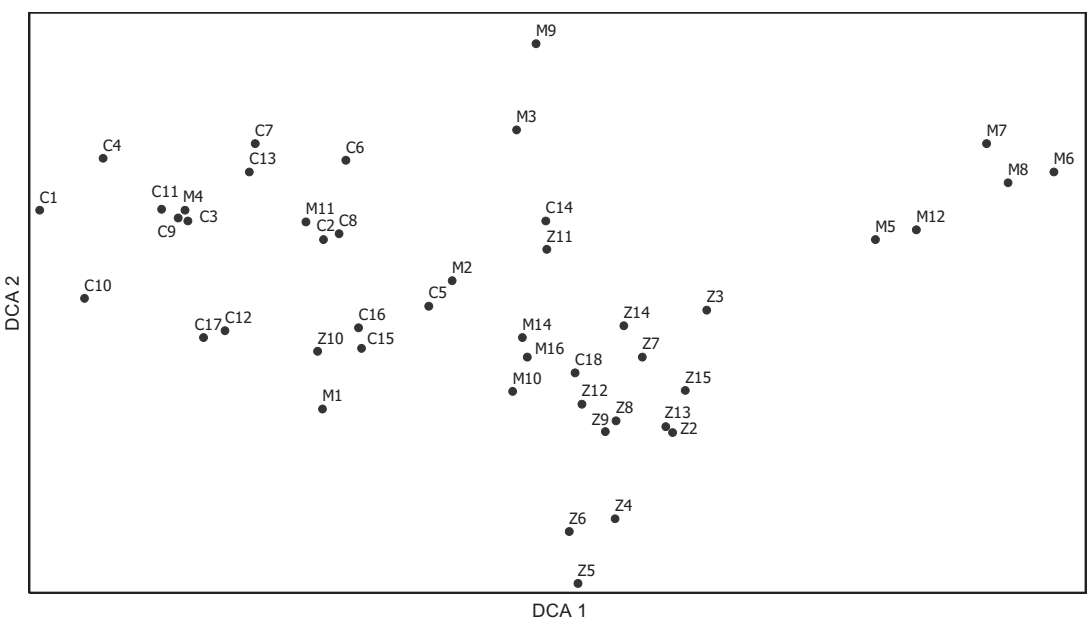

Fig. 3. Ordination of plots on first two axes of detrended correspondence analysis (DCA), based on vegetation structure variables. Z-labelled plots correspond to Monte Zerpa site, M to La Mucuy and C to La Carbonera.

with the site PCA axes. These facts indicate that in spite of similar floras between sites, forest structure is shaped to some extent at each site by species composition and abundances.

\section{DISCUSSION}

In spite of the relatively wide ranges of forest structure variables found along the cloud forest plots, most of them were not related to any measured environmental variable. In fact, only LAI exhibited a significant correlation, being higher on south-facing (2.7) than north facing slopes (1.7). Besides overcast skies, LAI decrease has been related to increasing slope angle (Kitayam \& Aiba 2002) and elevation (Leuschner et al. 2007; Moser et al. 2007). Low LAI in cloud forests has been attributed to low light income. Although slope angle, aspect, cloudiness and mountain shading would be expected to contribute to low light intensity in the high and steep mountains of the Venezuelan Andes, only $\mathrm{N}$ versus $\mathrm{S}$ slopes contrasted significantly, whereas east- and west-facing slopes exhibited comparable LAI. The reasons for these results are not clear, especially because near the equator, larger differences would be expected between east- and west-oriented slopes, because of higher cloud frequency in the afternoon (Azócar \& Monasterio 1980), which is also the pattern in our study area. The LAI values in our study are much smaller than for lowland tropical forests but similar to other cloud forest in the Andes. Acevedo et al. (2003) reported a mean LAI of 2.27 at $2300 \mathrm{~m}$ at La Mucuy. Leuschner et al. (2007) reported a range of 5.1 to 2.9 from 1050 to 3060 -m elevation in Ecuador. The simulated effect of frequently overcast skies on cloud forest productivity indicates that canopy carbon gain reaches a maximum at $\mathrm{LAI}=2$ (Bruijnzeel \&
Veneklaas 1998). Letts and Mulligan (2005) also reported low LAI associated with light limitation because of cloudiness in cloud forests.

Basal area was not correlated with any measured environmental variable at our study area, which was also observed in montane forests of Ecuador (Leuschner et al. 2007). Although we did not find a consistent pattern along the elevation gradient, Lovett et al. (2006) reported an increase in basal area with elevation. Takyu et al. (2002), Leuschner et al. (2007) and Nadkarni et al. (1995) found similar values of basal areas to those predominating in our study at $\mathrm{La}$ Carbonera and Monte Zerpa $(\mathrm{DBH}>10 \mathrm{~cm})$. Similar values were obtained by Aiba and Kitayama (1999), except on nutrient-poor soils and at higher elevations, where basal area was much lower. Basal areas in our study site had remarkably high variability, which has also been reported in some other studies (Acevedo et al. 2003; Sherman et al. 2005; Martin et al. 2007). At La Mucuy, besides the high variability, exceptionally large basal areas were measured at five plots with values ranging between 196 and $460 \mathrm{~cm}^{2} \mathrm{~m}^{-2}$. Acevedo et al. (2003) reported ranges from 6 to $345 \mathrm{~cm}^{2} \mathrm{~m}^{-2}$ on rather small plots $\left(64 \mathrm{~m}^{2}\right)$ at $2300 \mathrm{~m}$ at La Mucuy. Our high values are not explained by the 'additive basal area effect' (Midgley et al. 2002) because the increase in basal area was not associated with the contribution of a particular species (i.e. several species exhibited very high basal areas in these plots; Table 2).

Stem densities at our sites (Table 3) are in the range reported for other Andean cloud forests. Acevedo et al. (2003) reported values of 156 to 2031 stems per hectare at La Mucuy, while Kelly et al. (1994) found 23 stems per hectare at a site near La Mucuy. One source of this high variability is likely to be related to small plot size. Sherman et al. (2005) and Martin et al. 
(2007) observed similar stem density values in cloud forests of the Dominican Republic. Also, Nadkarni et al. (1995) report 555 stems per hectare at Monteverde (Costa Rica). Stem densities reported for a cloud forest in Borneo (Aiba \& Kitayama 1999) are almost twice as large as at our sites. Takyu et al. (2002) found an increase in stem density in cloud forests of Borneo under nutrient-poor conditions and with increasing slope, while Lovett et al. (2006) reported that stem density increased with elevation in Tanzania. Proctor et al. (1999) found that stem density and floristic composition correlated with water availability. In our study, the two sites with the greatest stem density were also the most species rich but were the sites with the lowest and highest annual precipitation (Table 1).

Canopy height showed lower variability than other forest structure variables at our study area and was not correlated with elevation or any other measured environmental factor. Leuschner et al. (2007) found significant differences in tree height along a 2000-m elevation range in Ecuador; Takyu et al. (2002) reported greater canopy heights on richer soils; and Aiba and Kitayama (1999) found greater decrease in canopy height with elevation on poorer soils along a 2500-m elevation gradient. Stunting appears to be common on tropical cloud forests, as mentioned earlier; however, the exact reasons for stunting remain unclear. At our site, severe stunting was observed at only one plot, our highest elevation plot at $3050 \mathrm{~m}$. Above 3000-m elevation, the forest gives way to shrubby and more open vegetation ('bosque preparamero'). This pattern differs from that observed by Sherman et al. (2005), who found stunting only in mixed broadleaved forest stands at high elevations, above which the stunted mixed forest is replaced by a tall pine forest. Similarly, Aiba \& Kitayama (2002) noted that particular species adaptations change the expected structural responses of the forest. For example, tall and high basal area Quercus forests are situated in cloud forests near the tropical timberline at Talamanca, Costa Rica (Kapelle et al. 1992). Therefore, the nature of structural changes along the elevation gradient may be the result of replacements by particular, well-adapted species and associated phylogenetic factors. In the absence of these species, more typical structural patterns may exist. In our study, the forest at $\mathrm{La}$ Carbonera had significantly greater canopy height than at La Mucuy. This was the result of large emergent tree species that occurred at the former (Retrophyllum rospigliosii).

Elevation exerts its effect on vegetation through climatic variables like temperature, precipitation and cloud cover. However, the lack of long-term temperature and precipitation data along elevation gradients in cloud forests still challenges the interpretation of its impact on forest structure and composition, and our study area is no exception. Some studies (Aiba \&
Kitayama 1999; Sherman et al. 2005; Dietz et al. 2006) have reported that the decrease in temperature with elevation is lower than the usual adiabatic lapse rate because of higher humidity and that precipitation is locally more unpredictable because of the effect of wind exposure and cloud level elevation. However, it is remarkable that over a fairly large elevation gradient $(1000 \mathrm{~m})$ and, presumably, a large temperature and precipitation gradient, an impact on forest structure was not apparent. Similar findings as those presented by Sherman et al. (2005) seem to challenge the view of an elevation gradient impacting vegetation structure in cloud forests. Local differences in precipitation, wind exposure, disturbance history and soil properties may introduce noise into the analysis of these relationships.

Multivariate analyses indicated that there was no interdependence between the environment and forest structure in our study area; however, most forest structure patterns remain unexplained. We suggest that, in accordance with Takyu et al. (2002), the interplay of a suite of environmental factors, generating a complex environmental gradient, influences the forest structure in different ways and results in the observed differences among study sites. Similarly, Aiba and Kitayama (1999) observed that temperature had different impacts on vegetation depending on nutrient availability. In our study area, forest structure was generally correlated with soil depth, $\mathrm{pH}$ and slope angle (Table 4). However, other environmental and biotic factors could influence forest dynamics with consequences for structure; for example, such features as wind exposure, disturbances, species pools, tree mortality rates and resprouting ability all influence cloud forest dynamics (Guariguata 1990; Aiba \& Kitayama 1999; Takyu et al. 2002; Aiba et al. 2005; Martin et al. 2007 and Lawton 1982). Although resprouting capacity of trees in our study area appeared common, information on species or frequency of sprouting is not available. Arriaga (2000) found that half of the species in a Mexican cloud forest possess that capacity, and Aiba and Kitayama (1999) reported increasing resprouting percentage with elevation. It is, however, interesting that in the vegetation structure ordination, plots are segregated by site, suggesting that sitespecific factors are making important contributions to the vegetation patterns. Therefore, it is likely that the complex interactions of environmental and biotic variables may play an important role in forest structure. For instance, La Carbonera, which had the greatest stem density, had by far the largest density of standing dead trees, which was concentrated in a few species. Sherman et al. (2005) also report uneven spatial patterns of stem density and standing dead trees.

Although species composition of the most abundant species was similar among sites (Table 2), our results do indicate a strong relationship between forest structure and composition. In fact, forest structure at the 
different sites may be, in part, the result of observed distinctive species composition, as some species are more important at some sites. For example, Retrophyllum rospigliosii, an emergent Podocarpaceae, determined the greater tree height at La Carbonera, the only site where this species is present. This may be determined by geographic barriers, dispersal limitations or random replacements. In our study area, although the species saturation curve levelled off, indicating an appropriate sample size (Schwarzkopf 2003), we found that species that grow very large at $\mathrm{La}$ Mucuy were not found in old forests plots at La Carbonera but were present there in younger stands. This may suggest that stochastic replacement can be important; however, several studies have shown that a large are associated with topography (Harms et al. 2001; Aiba et al. 2004). Also, a consistent pattern regarding aggregated tree spatial distribution in the tropics has been found to be either associated with habitat or related to dispersal/recruitment limitations (Hubbell 1979; Condit et al. 2000; Aiba et al. 2004), although no strong evidence of niche differentiation was suggested. In addition, impact of historical disturbances on forest structure and composition could not be evaluated, and further study of natural and human disturbances in the study area is warranted.

Most studies on the relationship of the environment with cloud forest structure attributes and composition have focused on single environmental variables usually split into a few categories, or even discrete points along an elevation gradient (Aiba \& Kitayama 1999; Takyu et al. 2002; Gould et al. 2006), with some notable exceptions (Sherman et al. 2005; Lovett et al. 2006). In our study, the sampling design was meant to avoid subjective plot location and to ensure representativeness along the dominant environmental gradients. By grouping the data into discrete categories (aspect, site, geology, etc.), we were able to explore the generality of the environmental relationships and, therefore, their power as predictors. Sherman et al. (2005), using a similar sampling approach, found a large overlap in vegetation types along the elevation gradient. This suggests that sampling at discrete points along a gradient (i.e. elevation) may be misleading. Therefore, to understand the responses of cloud forests to environmental gradients, sampling needs to be designed accordingly, as previously suggested by Lovett et al. (2006).

\section{ACKNOWLEDGEMENTS}

We wish to thank Henry Rodriguez for his support in the field and species identification, and Rafael Marquez, Ignacio Dugarte, Edecio Angulo, Francisco Dugarte, Javier Hernandez and Nelson Marquez for proportion of the species in tropical tree communities

their field assistance. We are also grateful to the following institutions: MER herbarium at the Universidad de Los Andes for their service, the Instituto de Desarrollo Forestal (INDEFOR) at the Universidad de Los Andes for their support at the La Carbonera site and the Instituto Nacional de Parques for allowing us to work at the Parque Nacional Sierra Nevada. We would like to acknowledge the financial support to this project provided by Cornell University, the International Foundation for Science (IFS) (Grant D /2875-1) and CDCHT of the Universidad de Los Andes (Grant C-871-97-01-C).

\section{REFERENCES}

Acevedo M. F., Ataroff M., Monteleone S. \& Estrada C. A. (2003) Structural and light heterogeneity in the understory of a Venezuelan Andean cloud forgst. Interciencia 28, 394403.

Aiba S. \& Kitayama K. (1999) Structure, composition and species diversity in an altitude-substrate matrix of rain forest tree communities on Mount Kinabalu, Borneo. Plant Ecol. 140, 139-57.

Aiba S. I. \& Kitayama K. (2002) Effects of the 1997-98 El Niño drought on rain forests of Mount Kinabalu, Borneo. F. Trop. Ecol. 18, 215-30.

Aiba S., Kitayama K. \& Takyu M. (2004) Habitat associations with topography and canopy structure of tree species in a tropical montane forest on Mount Kinabalu, Borneo. Plant Ecol. 174, 147-61.

Aiba S., Takyu M. \& Kitayama K. (2005) Dynamics, productivity and species richness of tropical rainforests along elevational and edaphic gradients on Mount Kinabalu, Borneo. Ecol. Res. 20, 279-86.

Arriaga L. (2000) Types and causes of tree mortality in a tropical montane cloud forest of Tamaulipas, Mexico. F. Trop. Ecol. $16,623-36$.

Ataroff M. (2001) Venezuela. In: Bosques Nublados Del Neotrópico (eds M. Kappelle \& A. D. Brown) pp. 500-25. INBio, Santo Domingo de Heredia.

Ataroff M. (2002) Precipitación e intercepción en ecosistemas boscosos de los Andes Venezolanos. Ecotropicos 15, 195-202.

Ataroff M. \& Sarmiento L. (2002) Las Unidades Ecológicas del Estado Mérida, Venezuela. Mérida.

Azócar A. \& Monasterio M. (1980) Estudio de la variabilidad meso y microclimática en el Páramo de Mucubají. In: Estudios Ecológicos En Los Páramos Andino (ed. M. Monasterio) pp. 225-62. Editorial de la Universidad de Los Andes, Mérida.

Bruijnzeel L. A. \& Proctor J. (1995) Hydrology and biogeochemistry of tropical montane cloud forests: what do we really know?. In: Tropical Montane Cloud Fors. (eds L. S. Hamilton, J. O. Juvik \& F. N. Scatena) pp. 38-78. Springer Verlag, New York.

Bruijnzeel L. A. \& Veneklaas E. J. (1998) Climatic conditions and tropical, montane forest productivity: the fog has not lifted yet. Ecology 79, 3-9.

Cavalier J. \& Goldstein G. (1989) Mist fog interception in elfin cloud forests in Colombia and Venezuela. F. Trop. Ecol. 5, 309-22.

Condit R., Ashton P. S., Baker P. et al. (2000) Spatial patterns in the distribution of tropical tree species. Science 288, 1414-8.

doi:10.1111/j.1442-9993.2010.02160.x
(C) 2010 The Authors

Journal compilation (C) 2010 Ecological Society of Australia 
Dietz J., Holscher D., Leuschner C. \& Hendrayanto (2006) Rainfall partitioning in relation to forest structure in differently managed montane forest stands in Central Sulawesi, Indonesia. For. Ecol. Manage. 237, 170-8.

Dirección de Cartografía Nacional (1977) Mapa Topográfico. Ministero del Ambiente y de los Recursos Naturales Renovables, Caracas.

Dirección de Geología (1976) Mapa Geológico y Estructural de Venezuela. Ministerio de Minas e Hidrocarburos, Caracas.

Gould W. A., Gonzalez G. \& Carrero Rivera G. (2006) Structure and composition of vegetation along an elevational gradient in Puerto Rico. F. Veg. Sci. 17, 653-64.

Grubb P. J. (1977) Control of forest growth and distribution on wet tropical mountains: with special reference to mineral nutrition. Ann. Rev. Ecol. Syst. 8, 83-107.

Guariguata M. R. (1990) Landslide disturbance and forest regeneration in the upper Luquillo Mountains of Puerto Rico. F. Ecol. 78, 814-32.

Haggar J. P. (1988) The structure, composition and status of the cloud forests of Pico Island in the Azores. Biol. Conservation $46,7-22$.

Harms K. E., Condit R., Hubbell S. P. \& Foster R. B. (2001) Habitat associations of trees and shrubs in a 50-ha neotropical forest plot. F. Ecol. 89, 947-59.

Hubbell S. P. (1979) Tree dispersion, abundance, and diversity in a tropical dry forest. Science 203, 1299-309.

Kapelle M., Cleef A. M. \& Chaverri A. (1992) Phytogeography of Talamanca montane Quercus forests, Costa Rica. F. Biogeogr. 19, 299-315.

Kelly D. L., Tanner E. V. J., Nic Lughadha E. M. \& Kapos V. (1994) Floristics and biogeography of a rain-forest in the Venezuelan Andes. F. Biogeogr. 21, 421-40.

Kitayam K. \& Aiba S. I. (2002) Ecosystem structure and productivity of tropical rain forests along altitudinal gradients with contrasting soil phosphorus pools on Mount Kinabalu, Borneo. F. Ecol. 90, 37-51.

Lawton R. O. (1982) Wind stress and elfin stature in a montane rain-forest tree - an adaptive explanation. Am. F. Bot. 69, 1224-30.

Letts M. G. \& Mulligan M. (2005) The impact of light quality and leaf wetness on photosynthesis in north-west Andean tropical montane cloud forest. F. Trop. Ecol. 21, 549-57.

Leuschner C., Moser G., Bertsch C., Röderstein M. \& Hertel D. (2007) Large altitudinal increase in tree root/shoot ratio in tropical mountain forests of Ecuador. Basic Appl. Ecol. 8, 219-30.

Lovett J. C., Marshall A. R. \& Carr J. (2006) Changes in tropical forest vegetation along an altitudinal gradient in the Udzungwa Mountains National Park, Tanzania. Afr. F. Ecol. 44, 478-90.
McCune B. \& Mefford M. J. (1999) PC-ORD for Windows. MjM Software Design, Gleneden Beach.

Martin P. H., Sherman R. E. \& Fahey T. J. (2007) Tropical montane forest ecotones: climate gradients, natural diturbance, and vegetation zonation in the Cordillera Central, Dominican Republic. F. Biogeor. 34, 1792-806.

Midgley J. J., Parker R., Laurie H. \& Seydack A. (2002) Competition among canopy trees in indigenous forests: an analysis of the 'additive basal area' phenomenon. Austral Ecol. 27, 269-72.

Ministerio de Energía y Minas (1997) Léxico Estratigráfico De Venezuela. Ministerio de Energía y Minas, Caracas.

Moser G., Hertel D. \& Leuschner C. (2007) Altitudinal change in LAI and stand leaf biomass in tropical montane forests: a transect study in ecuador and a pan-tropical meta-analysis. Ecosystems 10, 924-35.

Myster R. W. (1993) Spatial heterogeneity of seed rain, seed pool, and vegetative cover on two Monteverde landslides, Costa Rica. Brenesia 39-40, 137-46.

Nadkarni N. M., Matelson T. J. \& Haber W. A. (1995) Structural characteristics and floristic composition of a neotropical cloud forest, monteverde, costa-rica. F. Trop. Ecol. 11, 481-95.

Proctor J., Bruijnzeel L. A. \& Baker A. J. M. (1999) What causes the vegetation types on Mount Bloomfield, a coastal tropical mountain of the western Philippines? Glob. Ecol. Biogeogr. 8, 347-54.

Rich P. M. (1990) Characterizing plant canopies with hemispherical photographs. Remote Sens. Rev. 5, 13-29.

Rollet B. (1984) Études sur une forêt d'altitude des Andes Vénézuéliennes. Revue Bios Forêts Des Tropiques 205, 3-23.

Schwarzkopf T. (2003) Biophysical Characterization of Cloud Forest Vegetation in the Venezuelan Andes. Cornell University: $\mathrm{xi}+173$, Ithaca.

Sherman R. E., Martin P. H. \& Fahey T. J. (2005) Vegetationenvironment relationships in forest ecosystems of the Cordillera Central, Dominican Republic. F. Torrey Bot. Soc. 132, 293-310.

Soriano P. J., Díaz de Pascual A., Ochoa J. \& Aguilera M. (1999) Biogeographic analysis of the mammal communities in the Venezuelan Andes. Interciencia 24, 17-25.

Takyu M., Aiba S. I. \& Kitayama K. (2002) Effects of topography on tropical lower montane forest under different geological conditions on Mount Kinabalu, Borneo. Plant Ecol. 159, 35-49.

Takyu M., Aiba S. I. \& Kityama K. (2003) Changes in biomass, productivity and decomposition along topographical gradients under different geological conditions in tropical lower montane forests on Mount Kinabalu, Borneo. Oecologia 134, 397-404.

Tien S. J. (1979) A flow diagram for teaching texture-by-feel analysis. F. Agric. Edu. 8, 54-5. 